\title{
Танатологические мотивы
}

«Страшной мести» Николая Гоголя в контексте этнокультурных связей украинцев

\begin{abstract}
Г Константин Рахно
This article deals with the description of the posthumous destiny of the dead in the horror story A Terrible Vengeance by Mykola Gogol. It describes the patrimonial cemetery of the sorcerer, where all his ancestors were buried. Their corpses rise from their graves, but the first local dead man, the largest of them, cannot rise, and his movements cause earthquakes. These images can be fully understood only in comparison with Chuvash beliefs about the first buried dead person as the cemetery master and also with Zoroastrian and Ossetian mythological concepts. The Chuvashes and the Iranian-speaking nations, primarily the Ossetians, have parallels to the plot about a father coveting his daughter and killing his grandchild, the soul's wanderings during sleep, and other related motifs. Thus, the folkloric motifs on which the story is constructed help to reveal the ethnocultural connections of the early Ukrainians.
\end{abstract}

KEYWORDS: Mykola Gogol, thanatological motives, ethnology, literary studies, Ukraine, A Terrible Vengeance

Почти все критики единодушны в том, что «Страшная месть» Николая Гоголя, которая в первом издании была дополнена подзаголовком «Старинная быль», - одна из самых сильных и наиболее поэтичных его повестей. Это чрезвычайно сложное и крепко скомпонованное произведение, в причудливо закодированных мифологических структурах которого автор пытается прояснить причины упадка козацкой Украины. В ней устанавливаются основные мифологические оппозиции, которые касаются всех сочинений Гоголя на украинскую тематику, а сам автор проявляет глубокое понимание культуры и истории своего народа (Грабович 1994, 137-140). Давно обращено внимание на то, что «Страшная месть», перекликаясь с другими повестями «Вечеров на хуторе близ Диканьки» и «Миргорода», построена на знании Гоголем старины и народного быта (Шенрок 1893, 54-68). Даже те исследователи, кто полагал, что в основе лежат украинские варианты бродячих сюжетов, настаивали, что они обставлены у Гоголя подробностями из украинской народной жизни и поэзии (Петров 1902, 66-67). Верно и исторически точно писатель передавал дух козацкой эпохи (Каманин 1902, 102, 105, 107-108, 114-115, 128). Хотя звучало мнение, что влияние украинских народных сказаний и легенд на фантастическую 
тематику «Страшной мести» следует признать малосущественным и почти сплошь недостоверным (Державин 1927, 331), тем не менее, к каждому из мотивов повести можно найти соответствие в украинском фольклоре (Невірова 1909, 41). Исследования украинских фольклорных корней «Страшной мести» продолжаются (Стецюк 2004, 147; Иванов 2006).

Следует обратить внимание, что в «Страшной мести», воздвигнутой, как и большинство произведений великого писателя, на родном ему украинском быте и сказаниях, описывается родовое кладбище колдуна - отца Катерины, на котором встают из могил мертвецы, его деды и прадеды:

«На берегу виднелось кладбище: ветхие кресты толпились в кучку. Ни калина не растет меж ними, ни трава не зеленеет, только месяц греет их с небесной вышины.

- Слышите ли, хлопцы, крики? Кто-то зовёт нас на помощь! - сказал пан Данило, оборотясь к гребцам своим.

- Мы слышим крики, и кажется, с той стороны, - разом сказали хлопцы, указывая на кладбище. Но всё стихло. Лодка поворотила и стала огибать выдавшийся берег. Вдруг гребцы опустили весла и недвижно уставили очи. Остановился и пан Данило: страх и холод прорезался в козацкие жилы. Крест на могиле зашатался, и тихо поднялся из неё высохший мертвец. Борода до пояса; на пальцах когти длинные, еще длиннее самых пальцев. Тихо поднял он руки вверх. Лицо всё задрожало у него и покривилось. Страшную муку, видно, терпел он. «Душно мне! душно!» простонал он диким, не человечьим голосом. Голос его, будто нож, царапал сердце, и мертвец вдруг ушел под землю. Зашатался другой крест, и опять вышел мертвец, ещё страшнее, ещё выше прежнего; весь зарос; борода по колена и еще длиннее костяные когти. Еще диче закричал он: «Душно мне!» и ушел под землю. Пошатнулся третий крест, поднялся третий мертвец. Казалось, одни только кости поднялись высоко над землею. Борода по самые пяты; пальцы с длинными когтями вонзились в землю. Страшно протянул он руки вверх, как будто хотел достать месяца, и закричал так, как будто кто-нибудь стал пилить его жёлтые кости ...» (Гоголь 1979, 136-137).

После гибели колдуна мертвецы его терзают:

«Вмиг умер колдун и открыл после смерти очи. Но уже был мертвец, и глядел, как мертвец. Так страшно не глядит ни живой, ни воскресший. Ворочал он по сторонам мёртвыми глазами и увидел поднявшихся мертвецов от Киева, и от земли Галичской, и от Карпата, как две капли воды схожих лицом на него.

Бледны, бледны, один другого выше, один другого костистей, стали они вокруг всадника, державшего в руке страшную добычу. Ещё раз засмеялся рыцарь и кинул её в пропасть. И все мертвецы вскочили в пропасть, подхватили мертвеца и вонзили в него свои зубы».

И только самый большой, самый старый мертвец - его предок Петро, который совершил грех братоубийства, - не может встать. Он не может подняться из земли, чтобы грызть своего потомка:

«Еще один всех выше, всех страшнее, хотел подняться из земли; но не мог, не в силах был этого сделать, так велик вырос он в земле; а если бы поднялся, то 
опрокинул бы и Карпат, и Седмиградскую и Турецкую землю, немного только подвинулся он, и пошло от того трясение по всей земле. И много поопрокидывалось везде хат. И много задавило народу.

Слышится часто по Карпату свист, как будто тысяча мельниц шумит колесами на воде. То, в безвыходной пропасти, которой не видал еще ни один человек, страшащийся проходить мимо, мертвецы грызут мертвеца. Нередко бывало по всему миру, что земля тряслась от одного конца до другого; то оттого делается, толкуют грамотные люди, что есть где-то, близ моря, гора, из которой выхватывается пламя и текут горящие реки. Но старики, которые живут и в Венгрии, и в Галичской земле, лучше знают это и говорят: что то хочет подняться выросший в земле великий, великий мертвец и трясет землю» (Гоголь 1979, 164-165).

Такие представления о кладбище, на котором всем руководит самый старый предок, присущи и чувашской мифологии, где существует вера в так называемого главу кладбища (с̧ӑва пус̧е̌, масар пус̧е̌, с̧ӑва́ пос̧). На эту должность вступает первый похороненный, как правило, почтенный и мудрый, уважаемый всеми старец или пожилой мужчина, которому подчиняются все покойники независимо от ранга. Без его позволения они не могут уходить с кладбища. Правда, в позднейшее время в некоторых местностях пол и возраст первого покойника были неважными. С главой кладбища временами связывалось и самое наступление смерти, дескать, он и забирает жизнь, вставая из могилы к умирающему. Кладбище являлось его землей, у него те, кто «строит дом», то есть роет могилу, выпрашивали место для нового покойника, принося ему в жертву кусок хлеба и комочек сыра, которые отламывали и бросали на месте новой могилы. Иногда жертвовали деньги. Так, в деревне Старые Алгаши Симбирского уезда на действовавшем в начале XX века кладбище спрашивали позволения у некоего Ахмата, похороненного здесь первым. Старосту (масар пус̧лӑхе̌) могильщики просили при этом дать уголок земли. В его лице сосредотачивалось всё управление кладбищенским миром. Он должен был принять нового покойника, указать и отвести ему место, научить его порядкам загробного существования и т.д. Поэтому и могильщики не смели без его позволения начать рыть могилу. Только испросив разрешения у главы кладбища, они начинали копать (Трофимов 1993, 146; Трофимов 2003, 55; Салмин 1994, 213; Салмин 2007, 250; Месарош 2000, 46, 201; Комиссаров 1911, 375-376; Комиссаров 2003, 75-76; Денисов $1959,49)$. Первый поклон и угощение от посетивших должны были принадлежать ему. Во время поминок с него начинали угощать предков - ему первому приносили в жертву хмельной напиток суру (сӑра) и просили разрешения зажечь огонь, играть на скрипке и плясать после водружения нового надгробия в виде столба-юпы (юпа, йопа). Именно установление этого деревянного столба, как и у горцев Гиндукуша, завершало период траура по умершему. По верованиям чувашей, в поминках торжествовало добро: трагедия, как понимали они в древности, невозможна. Во Вселенной всё упорядочено и взаимосвязано, в ней нельзя отделить основное от второстепенного. Но мир, сотворённый участниками поминального обряда, как видим, уничтожается. Это нужно для того, чтобы предки без надобности, преждевременно, без приглашения не могли являться к живым. Промежуток времени от акта сотворения 
до акта разрушения предназначался для общения с усопшими. Встреча с ними была необходима живым для того, чтобы соединить, приобщить новопреставленных к миру мёртвых, то есть превратить недавно умерших в предков. При этом следует подчеркнуть, что ими не могли стать дети. И как ни парадоксально, все это считалось осуществлением связей поколений потустороннего мира. В преемственности предков главную роль играли пожилые люди, особенно те, которые пользовались авторитетом при жизни. Но масар (с̧ӑва́) пус̧е̌ - глава кладбища - всегда был один и тот же мужчина, законы связей поколений его как бы не касались (Трофимов 1993, 146, 179; Трофимов 2003, 55, 67; Салмин 2007, 280; Салмин 2009, 205; Нейкова 2008, 69; Neykova 2009, 166). Схожие представления о первом покойнике на кладбище как о будущем его старейшине зафиксированы у проживавшей рядом с чувашами мордвы Буинского уезда (Мокшин 2004, 147).

Глава кладбища практически является в позиции властителя, которая проявляется и в старости как мифологической метафоре верховности и власти. Этот прецедент описан в древних иранских и индоарийских текстах - первый царь на земле, который одновременно является первым умершим человеком, становится божеством подземного мира (Бойс 1987, 21; Нейкова 2008, 69; Neykova 2009, 166). И именно в иранском фольклоре прослеживается точная параллель представлению о том, что первый мертвец, лишенный возможности двигаться, обретает космические размеры, и его движения вызывают землетрясения. У осетин Бог, боясь, чтобы первый нарт не разрушил всю землю, постепенно заманивает его в самый центр земли, где огромный массив сковывает его богатырские члены, и первый нарт так и остался навеки в недрах земли. «С тех пор, - говорится в предании, - первый нарт, когда хочет вырваться оттуда, потрясает землю, из-за чего и происходит землетрясение». Это одна из древнейших легенд, которая объясняет явления природы. Однако первый нарт, прежде чем быть скованным землей, успевает оставить на ней свое потомство (Туганов 1977, 142).

Петро в повести совершил страшный грех, связанный с ложью и предательством, а в Яште говорится о грехопадении Йимы. Дошедшие зороастрийские тексты не сообщают подробностей этого сюжета. Грех Иимы в разных источниках определяется по-разному: Заратуштра ставит Йиме в вину потребление в пищу мяса рогатого скота (Ясна, XXXII, 8); в Яште (XIX, 33-38) Йима представлен «солгавшим», «взявшим на ум лживое, неистинное слово» и «утратившим Хварно»; согласно Бундахишну $(17,4)$, он возомнил себя богоравным (Авеста 1993, 158-159; Авеста 1997, 385; Зороастрийские тексты 1997, 289; Рак 1998, 163; Вертієнко 2015, 16).

Наряду с возможными тюркскими соответствиями, этимология чувашского пус̧/ пос̧ имеет параллель с родственным индоиранским словом pati - 'вождь', 'глава'. Несомненный научный интерес представляет и родство между чувашским словом çăва ‘кладбище' и санскритскими с̧āva - ‘трупный (запах)', çáva - ‘труп, останки’, çávya - 'похоронный обряд’, çva-bhra - 'яма; пещера; преисподняя, ад’ (Салмин 2010, 58, 190; Салмин 2016, 522). У чувашей надгробие с̧ӑва пус̧е̌ отличалось своими размерами, оно было выше других и обычно располагалось в центре кладбища. Это единственная юпа, которую живые заменяли новой, если старая завалится 
(Трофимов 1993, 146; Трофимов 2003, 55). Очевидно, это намек на его гигантские размеры. Одно из древних кладбищ некрещёных чувашей возле села Сабакаево, расположенное на древнем кургане, называлось Улӑп те̌ми 'Холм великана'. Хоронить там перестали давно, но ещё сохранялись деревянные скульптурные изображения, и поминки всё ещё проводились каждой весной и осенью (Трофимов 1993, 152). Дополнительная параллель с повестью Гоголя прослеживается и в том факте, что кладбища некрещёных чувашей, в том числе и средневековые, всегда были расположены на открытой возвышенности у реки (Трофимов 1993, 66, 152; Трофимов 2003, 55; Нейкова 2008, 74; Neykova 2009, 172).

Важно, что и название столпообразного надгробия, и ритуального хмельного напитка, и сыра у чувашей являются индоиранскими по происхождению. Чувашское юпа, йопа 'столб', ‘столб, изображающий покойника', юпа мунђи 'мытье в бане после поминок', юпа-палли 'грубое деревянное изображение покойника, которое ставят на могилу при похоронах', юпа туни 'отправление поминок (в том числе и православных)', юпа ту 'справлять поминки', юпа тӑратни 'обряд при котором остатки костей после поминального угощения бросают на избранное место’, юпа yŭăхе̌ ‘октябрь'; юпа уйӑх, йопа ойӑх 'ноябрь, месяц поминок’ (Ашмарин 1994а, 342-347; Федотов 1996, 488), пока что остаётся в словарях без этимологии, как и мордовское юба 'столб на мольбище' (Мельников 1981, 61). Предложение связать его с бурято-монгольским обоо 'насыпь', 'курган', 'куча', ‘груда', обон 'сопка, где совершался религиозный обряд’, калмыцким ова 'курган’ (Ершов 1964, 369) ничем не обосновано, и скорее можно предположить обратное заимствование из буддийской практики у монголов. Попытки же соотнести это чувашское слово и понятие с ведическими традициями пока неубедительны (Трофимов 2003, 55-56), хотя и вполне правомерны. Ведь можно привлечь данные об индоарийских жертвенных столбах уūpa, aśvayūpa и подобных (Салмин 1994, 224; Топоров 1974, 65). Весьма характерные детали сообщаются, в частности, в Ригведе (III, 8. 9-10):

«Словно гуси, выстроившиеся рядами, прибыли к нам (жертвенные) столбы, одетые в светлое.

Поднимаемые перед (огнем) поэтами, боги вступают на путь богов.

Они выглядят, как рога рогатых (животных), столбы с навершиями, (стоящие) на земле» (Ригведа 1989, 299, 694).

Эти данные Ригведы могут рассматриваться как довольно точное изображение ритуальных конструкций, широко используемых в шаманских культурах (Топоров 1974, 66). Индоарийское aśvayūpa - коновязь, столб, к которому привязывается жертвенная лошадь, упоминается уже в древнейшем описании жертвоприношения коня, в гимнах Ригведы (I 162. 6) (Ригведа 1989, 196, 643). Оно является функциональным эквивалентом мирового дерева. Космический символизм столба, то есть его роль посредствующего, связующего звена, объясняется тем, что к нему привязывалась жертва. Жертвенная лошадь устанавливала связь между двумя космическими зонами 
- миром людей и миром богов. Связь жертвы столба особенно наглядно подтверждается этимологией названия столба - уйра, образованного от корня уи- ('привязывать, связывать') при помощи форманта -р-. В дальнейшем символизм столба и жертвы был переосмыслен таким образом, что установление столба стало само по себе ритуалом, воспроизводящим акт сотворения вселенной. Aśvayūpa (буквально 'конский столб' или 'конь-столб') полностью соответствует бурятскому ритуальному термину азарга-сэргэ (от азарга 'жеребец’ и сэргэ ‘столб'; в целом - название березы, вырываемой с корнем из земли; к ней привязывается при жертвоприношении конь) (Огибенин 1968, 17; Иванов 1974, 99-101; Топоров 1974, 69; Дандекар 2002, 142). Водружение юпы у чувашей тоже было сотворением мира, что выражалось в зажигании огня и свечей, исполнении речитативного гимна-молитвы в честь богов и предков, возлияниях, угощении, музыке, пении и танцах (Трофимов 2003, 131). В повести Гоголя недаром упомянуты ветхие кресты. У чувашей упавшие от времени столбы-юпа, равно как и кресты, издревле и по сей день не принято не только заменять и ремонтировать, но и поднимать и устанавливать вновь. Если юпу обновить, то случится вторая смерть. Пожилые обижаются на молодых, пытающихся хотя бы приподнять упавший намогильный деревянный знак. Каменные надгробия воспринимались как оскорбление покойников. Характерно, что ещё в конце XIX - начале XX вв. крещёные чуваши во время обряда юпа изготовляли не столбы, а деревянные кресты, что, естественно, не соответствовало православным канонам (Месарош 2000, 204; Салмин 2007, 280, 285-289; Нейкова 2008, 63; Neykova 2009, 160-161).

Сӑра 'пиво', алтан (автан) сӑра 'петушиное пиво' - название обряда; ял сӑри название 'обряда в честь нового урожая'; сӑра-качка 'пиво и связанные с его приготовлением хлопоты'; сӑра курки название 'особой раскрашенной деревянной чашки для питья пива'; сӑра чӱк(е̌) название 'моления с пивом' и т.д. (Ашмарин 1994b, 271-273). Финно-угорские формы родственны: марийское сыра, сырӓ 'пиво, квас', удмуртское sura, sur ‘пиво', śe्रd-sur ‘вино’ (буквально ‘чёрное пиво’), коми sur 'пиво', ma-sur 'пиво медовое ', хантыйское sar, sǒr 'пиво домашнего приготовления', мансийское sór ‘пиво', sor-vit ‘водка', венгерское sör 'пиво'. Относительно мансийского sór этимологи считают, что оно в мансийский язык попало при посредстве предков удмуртов и коми, то есть в общепермскую эпоху. Все они предполагают связь слова с санскритским súrā - согласно древнеиндийской традиции, грубым опьяняющим напитком, используемым низшей кастой шудр. Его название традиционно считается заимствованием из неизвестного иранского языка, хотя форма слова соответствует индоарийскому источнику - санскритскому súrā 'хмельной напиток (из зёрен)', пали, пракрит surā 'алкогольный напиток', маратхи, пахари sūr ‘то же' при авестийском hurā- 'название алкогольного напитка; молочное вино, кумыс', среднеперсидском hur, персидском shire 'алкогольный напиток' (Егоров 1964, 183; Федотов 1996, 29-30; Лыткин, Гуляев 1970, 266; Борлукова 1997, 19; Joki 1973, 317; Rédei 1986, 76-77; Baitchura 1982, 58-59; Golden 2006, 19; Misra 2005, 200, 203). Этнологи полагают, что эти факты свидетельствуют в пользу индоиранского происхождения пивоварения и связанных с пивом обычаев у чувашей и финно-угров (Салмин 2010, 78-79; Борлукова 1997, 19-25; Напольских 2015, 57-58). 
Сыр в районах теплого и жаркого климата - единственный способ сохранения питательных свойств молока (Салмин 2010, 67). Чувашское чӑкӑт 'сыр', 'сырок', как и караимское с̌əğət, марийское с̌əgət, венгерское sajt, восходят к осетинскому cyxt, ciğd 'сыр', родственному ваханскому te $\mathrm{d}$ 'острый', древнеиндийскому tikta 'острый по вкусу'. Это несомненное указание на связь между аланами и предками чувашей. При этом следует учесть оригинальность всей остальной терминологии осетинского молочного хозяйства (Munkaczi 1904, 329; Егоров 1964, 318; Федотов 1996, 400; Абаев 1949, 35, 58; Абаев 1958, 328; Róna-Tas 1986, 200). Языковеды давно показали несостоятельность попыток связать чувашский термин с османским joyurt, якутским suorat 'кислое молоко' (Gombocz 1912, 113). Этнологи тоже признают индоиранское происхождение этого слова и указывают, что сыр у чувашей часто жертвовали душам предков (Салмин 2010, 67). Хлеб, пиво и сыр выступали в качестве основных жертвенных даров, поскольку они являлись главными продуктами жизнеобеспечения. Включение в состав жертвы сыра само по себе указывает на скотоводческие, степные, то есть в исторической перспективе иранские истоки всего обряда и сопутствующих верований, столь похожих на украинские.

Определённый интерес представляет плата первому покойнику за землю деньгами. Чуваши, укладывая родственника в гроб, в рот клали монету. К этому же семантическому ряду следует отнести эпизод «вкладывания» монеты в вырез намогильного столба, означающий «рот» умершего. Это действие происходило во время нахождения столба на кровати бывшего владельца. Деньги можно было также вложить в руки или карман усопшего при укладывании в гроб (Салмин 2009, 205-206; Салмин 2010, 91-92). Украинцы также бросали в могилу деньги как плату за место на кладбище его хозяину (Чубинский 1877, 710; Иванов 1909, 249-250; Афанасьев 1865, 577; Ящуржинский 1890, 131; Вакарелски 1990, 93-95). Очевидно, представление о последнем у них также является индоиранским наследием. Иранисты предлагают четыре мифологемы с жертвенной монетой: оберег, для приобретения пищи, плата владыке подземного мира, плата за перевоз через воду. «...В обширном регионе расселения иранцев существовало представление о водном потоке, который должна пересечь душа праведного покойника, чтобы попасть в загробный мир. Судя по ряду свидетельств, эти верования существовали и у иранцев Средней Азии. У них было распространено обыкновение помещать вместе с покойником монеты», а у согдийцев «монета вкладывалась в рот покойнику...» (Литвинский, Седов 1984, $159,161)$. Объясняя отсутствие в некоторых могилах монеты, археологи отмечают, что давали её не всем, ибо иного мира в таких вариантах можно было бы достичь без пересечения водной преграды (Литвинский, Седов 1984, 150-169). Конечно, это определённое сужение круга возможных причин. Даже в качестве преграды на пути в иной мир, кроме воды, могут быть лес, гора, овраг и т.д., ибо, заблудившись в лесу, например, можно оказаться в ином мире (Салмин 2010, 92). Как показали исследования, поверья, описанные выше, восходят ко времени индоиранской общности. Есть данные, позволяющие предполагать индоевропейское происхождение этого представления. Наиболее устойчивым оно оказалось в погребальном обряде Бактрии - Тохаристана (Салмин 2016, 495). Как видим, украинский и чувашский 
материал перекликаются с представленными там культурами. Подобный обычай существовал и у дунайских болгар: деньги клали покойному либо в карман, либо в руку, либо на лоб или в рот, чтобы тот смог откупиться на том свете (Вакарелски 1977, 492).

Описывая место погребения предков колдуна, Гоголь упомянул украинский обычай сажать на кладбище калину. У чувашей тоже был обычай сажать у могилы калину (че̌рӗ палан йывӑс̧не) (Одюков 1965, 180-181).

Модуляция между внешним и внутренним источником проклятия козацкой Украины подается у писателя в инцесте; хотя до него дело не доходит, уже само намерение предвещает беду и структурно равно действию. Попытка принадлежит тому, кто одновременно является чужаком и отцом. Ко всем преступлениям колдуна добавляются ещё и противоестественные наклонности. Исследователи отмечают, что такое объяснение могло принадлежать только художнику с исключительной интуицией и глубоким пониманием собственной культуры и истории (Грабович 1994, 137-140). Мотив отца, добивающегося противоестественной любви к себе от дочери, встречается в сказках украинцев и белорусов (Чудаков 1906, 26-27). Но этот же сюжет свойственен и фольклору ираноязычных народов, который перекликается с повестью, в том числе и в моменте убийства сына Катерины. В талышской сказке, умирая, жена велела мужу взять женщину, которой придётся впору её кольцо. Тот человек стал искать, но на чей палец он ни надевал кольца - оно не подходило. Годилось оно только дочери, и отец решил жениться на ней. Та плакала и говорила, что это невозможно. Отец ответил, что тогда убьёт её. Дочь согласилась, но попросила отпустить её в поле. Отец привязал к её ноге верёвку, но дочь отвязала верёвку, убежала и пришла в лес. Отец, потеряв её, вернулся домой. Встретив плотника, она попросила построить ей дом на берегу реки. Приехав напоить лошадь, старший из трёх царевичей сперва заметил в реке женский волос, а потом увидал на берегу девушку, подобной которой не было. Решив женить сыновей, царь велел каждому из них бросить по яблоку. Один бросил яблоко дочери визиря, другой дочери векиля, а старший - на дорогу. Три раза ему давали яблоко, и три раза он бросал его на дорогу. Царь сыграл свадьбу двух своих сыновей, а старший сын рассердился и ушёл из дому. Десять дней спустя царь забеспокоился, где он, и отправил визиря на поиски. Визирь нашёл царевича на берегу с незнакомой девушкой и рассказал царю. Увидев её, царь одобрил выбор, и они вернулись домой, чтобы сыграть свадьбу. Через год жена родила царевичу сына, один локон которого был золотой, а другой серебряный. Царь его очень полюбил. Но однажды её отец под видом разносчика проник во дворец, отрезал ребёнку голову, а нож положил в карман матери. Когда царь обнаружил внука с перерезанной шеей, гость посоветовал обыскать всех, и у невестки нашли нож. Ей вырезали глаза и дали их в руки. Она взяла тело ребёнка, пошла на берег реки и стала молиться. После этого прилетели три голубя; она приложила по лапке двух первых к глазницам и прозрела, а лапку третьего потёрла о шею сына, шея зажила, и он ожил. Некоторое время она прожила на берегу реки. Когда царевич с визирем и векилем отправились на охоту, она послала сына пригласить их остановиться в её доме. Она приготовила вкусное 
кушанье и велела им через сына не рвать цветы, но сама сорвала и положила их под одеяло царевича. Утром велела сыну узнать, кто сорвал цветы, тот обнаружил их у царевича. Потом она с сыном пришла к нему, он узнал жену и увёз к себе домой (Миллер 1930, 90-92). В осетинской сказке рассказывается, как жили-были жена и муж, и была у них единственная дочь. Жена заболела, позвала своего мужа и дала ему свой башмак и напёрсток, завещав ему, когда она умрёт, не жениться ни на ком, кроме той, кому подойдут эти башмак и напёрсток. Жена умерла, муж решил жениться. Носит туда-сюда башмак умершей жены, но башмак никому не годится. Пришёл домой, надел башмак на ногу своей дочери, он оказался ей впору. Вдовец предложил дочери жениться на ней. Дочь удивилась, мол, разве такое бывало когда-нибудь. Носит-носит отец башмак. То одной на ногу оденет, то другой, но башмак никому не годится. В конце концов, он пришёл домой, опять примерил башмак на ногу дочери, башмак подошёл. Опять сказал ей отец, что женится на ней. Тогда дочь ему ответила, что если он не оставляет её в покое, пусть сделает то, что она ему скажет, и она даст согласие. Отец согласился. Дочь сказала построить дом в семь этажей с потайными помещениями, чтобы, если кто-нибудь придёт его убивать, она бы его спрятала. Отец построил хороший дом, посередине установил большую деревянную трубу. Дочь согласилась выйти замуж за отца, и они жили в этом доме. Однажды отец куда-то ушёл, дочь же завернулась в волчью шкуру и залезла на эту трубу. Отец пришёл домой, смотрит по углам дома, а дочери нигде нет. Он обеспокоился, где её искать, разозлился, утопил весь дом в большой реке, оставив одну трубу, затем воротился в своё прежнее бедное жилище. Дочь, завернувшаяся в волчью шкуру, вылезла из реки волком и побежала в сторону леса. По дороге она встретила одного парня, тот очень обрадовался, что у него будет обученный волк. Привёл он её домой и завёл в комнату из золота. У этого парня было семь сестёр. Они каждый вечер ходили к реке купаться. Девушка тоже отправлялась за ними, но они не пускали её с собой. После нескольких раз юноша сказал, что поведёт волка на берег реки, посмотреть, что тот будет делать. Как только они подошли к берегу реки, девушка сбросила свою волчью шкуру и стала купаться. Юноша схватил волчью шкуру и унёс. Девушка заплакала и попросила вернуть ей шкуру. Юноша отдал ей волчью шкуру, но приведя её домой и запершись с ней в комнате, поставил сёстрам ультиматум, что женится на ней. Сестры подали повозку. Юноша открыл дверь, и девушка вся золотая вышла из комнаты. Они поехали в церковь и повенчались, став мужем и женой. Через некоторое время у них родился золотокудрый мальчик. Родители очень обрадовались ему. Как-то раз к ним попал отец девушки. Они не знали, кто он, и взяли его к себе в батраки. Через несколько дней дед отрезал золотую прядь у мальчика и убил его, а окровавленный нож положил в карман матери. Мать с отцом ужаснулись, что кто-то поднял руку на их мальчика. Они удивлялись, кто мог сделать это. Батрак предложил поискать, у кого в кармане окровавленный нож, тот ведь и сделал это, и отрезать тому руки. Нашли окровавленный нож в кармане у матери и отрезали согласно уговору ей руки. Саму её отнесли в поле и там оставили. Несчастная женщина причитала в поле, но внезапно около неё появился ангел (зæд) и спросил, что с ней, 
кто с ней это сделал. Она рассказала, что был у неё ребенок с золотой прядью, её отец устроился к ним батраком, убил её ребенка и свалил вину на неё. Поэтому с ней так поступили. Ангел ей молвил, что пойдёт и пустит золотой родник, и как только она услышит его звук, то должна пойти и омыть этой водой свои раны и раны своего ребенка, и они оба станут в семь раз лучше, чем были. Женщина согласилась. Ангел ушёл, и в тот же миг начал журчать родник. Женщина побежала, омыла водой раны себе и ребёнку, они стали в семь раз лучше, чем были. Ангел увёл их оттуда и завёл в золотую башню. Велел женщине жить здесь со своим ребенком и никого к себе не пускать. Она долго прожила в этом доме. Как-то раз к ней постучались двое мужчин. Женщина выглянула к ним. Один из них оказался её отец, который убил её мальчика. Она сделала вид, что не узнала его, завела их в дом. Накрыла им стол, напоила отца. Затем гостя завела в свою комнату, а отца отправила спать в сад. А сад был чудесный: там были разные фрукты и цветы, водились змеи, которые могут проглотить человека целиком. И рос там удивительный виноград. Она наказала отцу не трогать виноград, а то отдаст на съедение змеям. Тот заверил, что вообще не ест виноград. Когда он заснул, дочь вымазала нож виноградным соком и положила ему в карман. Утром она вышла и начала считать виноград. Отец сказал, что ничего не срывал. Женщина заявила, что надо поискать нож в виноградном соке. И отец неприятно удивился, когда в его кармане оказался такой нож. Женщина в ответ сказала, что как он не ел этот виноград, так и она не убивала своего ребёнка, но он поступил вероломно, свалив на неё свою вину, из-за чего она подверглась испытаниям. Она отдала мужчину, бывшего её отцом, на съедение змеям. Муж её возвратился к ней, и жили они хорошо (Сокаева 2010, 156-164). Много сказок об отце, возжелавшем жениться на дочери, было известно персам (Персидские сказки 1958, 77-86; Marzolph 1984, 106-107). На собственной дочери постановил жениться царь в язгулямской сказке, не найдя никого достойнее, и дочь совершила побег (Сказки народов Памира 1976, 389-390). Горные таджики в Дарвазе и верховьях Ванджа рассказывали, как царь полез на дерево, поранился о ветки, кровь капнула на снег. Он велел найти ему невесту такую же белую и красную. Старуха сказала, что это его дочь; он стал готовить свадьбу. Брат девушки спрятал её в сундук и спустил по реке. Тот сундук нашёл сын другого царя и взял девушку в жёны (Семенов 1900, 9).

В чувашской сказке, умирая, жена попа даёт ему свой перстень, велит жениться на той, кому подойдет. Он никому не подходит, но дочь случайно надела, и поп хочет на ней жениться, она убегает. Царский сын на ней женился, у них родился сын. Когда царевич уехал, поп пришел неузнанным, зарезал младенца. По наущению попа, его дочери отрубили руки и изгнали вместе с мёртвым ребёнком, но в воде реки её руки отросли, а таинственный голос научил, как воскресить ребёнка соком голубых цветов. Когда он вырос, то изобличил попа и воссоединил родителей (Чувашские сказки 1937, 237-247). Попом выступает отец-кровосмеситель и в некоторых украинских и осетинских текстах (Чудаков 1906, 26-27; Бязыров 1958, 334-335), а в повести пан Данило Бурульбаш саркастично называет своего тестя «турецким игуменом» (Гоголь 1979, 142). 
Душа Катерины представлена в повести сходно с русалкой (Шенрок 1893, 67). Принципиально неправы были те критики, которые возводили отделение души от тела во время сна к влиянию немецких романтиков (А. К., Ю. Ф. 1902, 641-647; Чудаков 1908, 85-86). Представление о душе как об особом двойнике человека, о самостоятельном существовании человеческой души (чун) и тела довольно хорошо прослеживается и на материалах мифологии и фольклора чувашей. В их воззрениях вера в двойственность человеческой природы отразилась вполне определённо. В прошлом чуваши, как и многие другие народы, верили, что если душа временно уходит из тела, то наступает состояние сна; если она уходит навсегда - смерть. Поэтому у них, например, запрещалось внезапно будить спящего из опасения, что при этом душа не успеет вернуться и вселиться в покинутое тело, потому что во время сна человека она может находиться далеко, и человек в таких случаях обязательно заболеет или умрёт. По представлению чувашей, во время сна и в момент смерти душа покидает тело человека через его естественные отверстия - нос и рот. Тогда с ней могут общаться люди, и душа рассказывает им, где она была. После возвращения из странствий, если душе никто не помешает, она возвращается в покинутое тело. Когда спящий просыпается, он рассказывает сны, аналогичные рассказу души о своих странствиях (Денисов 1959, 23-24). У осетин тоже существовало поверье, что души некоторых людей во время сна оставляют тело и осуществляют странствие в таинственную страну, из которой могут принести или счастье и урожай, или болезни (Миллер 1882, 270-272; Чибиров 2008, 37).

Аналогичное украинское верование отображено в быличках (Чудаков 1906, 26; Гринченко 1897, 109; Гура, Терновская, Толстая 1983, 69-70; Народная 2012, 33-34) и «Страшной мести» Гоголя.

И отдельное место занимает развязка повести, в которой тоже пытались видеть влияние немецкого романтизма и литературы эпохи Возрождения (Dauenhauer 1936, 317-318; Driessen 1965, 109). Дело в том, что, по мнению исследователей, иранский миф о первой смерти не заканчивается собственно смертью первого «смертного» героя. Он содержит элементы мести и победы потомка/родственника погибшего героя над убийцей (и часто узурпатором), которая и восстанавливает справедливость и природное равновесие на космическом и социальном уровнях. Эти танатологические представления бытовали и у ираноязычных кочевников Северного Причерноморья (Вертієнко 2015, 16-17, 64-65), от которых они были впоследствии унаследованы украинцами. Отмечалось также, что показанное у Гоголя пожирание предками потомка - это реликт огромной мистической темы, прослеживаемой к иранскому манихейскому «самоуничтожению материи» (Вайскопф 2002, 77). Оно сопоставимо с пожиранием отца-грешника змеями в осетинской сказке, особенно если учесть, что змея у осетин может служить воплощением предка. В основе «Страшной мести» лежат древние фольклорные сюжеты, восходящие к этническому субстрату украинцев и показывающие их этнокультурные связи. Это ещё одно доказательство того, что образы Николая Гоголя принадлежат народной традиции, а не являются литературными конструктами. 


\section{ЛИТЕРАТУРА}

Абаев, В.И., Историко-этимологический словарь осетинского языка, т. І: А-К', Москва, Ленинград, 1958.

[Abajev, V.I., Istoriko-etimologičeskij slovar osetinskogo jazyka, t. I: A-K', Moskva, Leningrad, 1958.]

Абаев, В.И., Осетинский язык и фольклор, т. 1, Москва-Ленинград, 1949.

[Abajev, V.I., Osetinskij jazyk i folklor, t. 1, Moskva-Leningrad, 1949.]

Авеста: Избранные гимны. Из Видевдата, перевод с авестийского, предисловие, примечания и словарь Ивана Стеблин-Каменского, Москва, 1993.

[Avesta: Izbrannyje gimny. Iz Videvdata, perevod s avestijskogo, predislovije, primečanija i slovar Ivana Steblin-Kamenskogo, Moskva, 1993.]

Авеста в русских переводах [1861-1996], составление, общая редакция, примечания и справочный раздел И.В. Рака, Санкт-Петербург, 1997.

[Avesta v russkih perevodah [1861-1996], sostavljenie, obščaja redakcija, primečanija i spravočnyj razdel I.V. Raka, Sankt-Peterburg, 1997.]

А.К., Ю.Ф., «Страшная месть» Гоголя и повесть Тика «Пьетро Апоне», in: Русская старина: Ежемесячное историческое издание, год XXXIII, март, Санкт-Петербург, 1902, с. 641-647.

[A.K., Ju.F., «Strašnaja mest» Gogolja i povest Tika «Pietro Apone», in: Russkaja starina: Ežemesjačnoje istoričeskoje izdanije, god XXXIII, mart, Sankt-Peterburg, 1902, s. 641-647.]

Афанасьев, А.Н., Поэтические воззрения славян на природу: Опыт сравнительного изучения славянских преданий и верований, в связи с мифическими сказаниями других родственныхх народов, т. 1, Москва, 1865.

[Afanasjev, A.N., Poetičeskije vozzrenija slavjan na prirodu: Opyt sravnitelnogo izučenija slavjanskih predanij i verovanij, v svjazi s mifičeskimi skazanijami drugih rodstvennyh narodov, t. 1, Moskva, 1865.]

Ашмарин, Н.И., Словарь чувашского языка, т. 4: Ў-Ц̆-Е̌-Й, Чебоксары, 1994а.

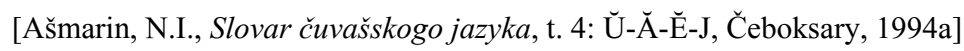

Ашмарин, Н.И. Словарь чувашского языка, т. 11-12: С-С̧, Чебоксары, $1994 \mathrm{~b}$.

[Ašmarin, N.I. Slovar čuvašskogo jazyka, t. 11-12: S-Ş, Čeboksary, 1994b.]

Бойс, Мэри, Зороастрийцьл. Верования и обычаи, Москва, 1987.

[Boyce, Mary, Zoroastrijcy. Verovanija i obyčai, Moskva, 1987.]

Борлукова, Наталья, Удмуртское sur 'пиво'. Терминология пивоварения у финно-угорских народов, in: Linguistica Uralica, vol. XXXIII, № 1, Tallinn, 1997, с. 19-26.

[Borlukova, Natalja, Udmurtskoje sur 'pivo'. Terminologija pivovarenija u finno-ugorskih narodov, in: Linguistica Uralica, vol. XXXIII, № 1, Tallinn, 1997, s. 19-26.]

Бязыров, А.Х., Опыт классификации осетинских народных сказок по системе Аарне Андреева, in: Известия Юго-Осетинского Научно-исследовательского института АН Грузинской ССР, вып. IX, 1958, с. 309-346.

[Bjazyrov, A.H., Opyt klassifikacyi osetinskih narodnyh skazok po sisteme Aarne - Andrejeva, in: Izvestija Jugo-Osetinskogo Naučno-issledovatelskogo instituta AN Gruzinskoj SSR, vyp. IX, 1958, s. 309-346.]

Вайскопф, М.Я., Сюжет Гоголя: Морфология. Идеология. Контекст, Москва, 2002. 
[Weisskopf, M.Ja., Sjužet Gogolja: Morfologija. Ideologija. Kontekst, Moskva, 2002.]

Вакарелски, Христо Томов, Етнография на България, София, 1977.

[Vakarelski, Hristo Tomov, Etnografija na Blgarija, Sofija, 1977.]

Вакарелски, Христо, Български погребални обичаи: Сравнително изучаване, София, 1990.

[Vakarelski, Hristo, Blgarski pogrebalni običai: Sravnitelno izučavane, Sofija, 1990.]

Вертієнко, Ганна, Іконографія скіфської есхатології. Київ, 2015.

[Vertijenko, Ganna, Ikonografija skifskoji eshatologiji. Kyjiv, 2015.]

Гоголь, Н.В., Избранные произведения в 2-х томах, том 1, Киев, 1979.

[Gogol, N.V., Izbrannyje proizvedenija v 2-h tomah, tom 1, Kijev, 1979.]

Грабович, Григорій, Гоголь і міф України, in: Сучасність, № 10, 1994, c. 137-150.

[Grabovyč, Grygorij, Gogol i mif Ukrajiny, in: Sučasnist, № 10, 1994, s. 137-150.]

Гринченко, Б.Д., Этнографические материалы, собранные в Черниговской и соседних с ней губерниях, вып. 2, Чернигов, 1897.

[Grinčenko, B.D., Etnografičeskije materialy, sobrannyje v Černigovskoj i sosednih s nej gubernijah, vyp. 2, Černigov, 1897.]

Гура, А.В., Терновская, О.А., Толстая, С.М. Материалы к полесскому этнолингвистическому атласу, in: Полесский этнолингвистический сборник: Материалы и исследования, Москва, 1983, с. 49-153.

[Gura, A.V., Ternovskaja, O.A., Tolstaja, S.M. Materialy k polesskomu etnolingvističeskomu atlasu, in: Polesskij etnolingvističeskij sbornik: Materialy i issledovanija, Moskva, 1983, s. 49-153.]

Дандекар, Р.Н., От вед к индуизму: Эволюиионирующая мифология, Москва, 2002.

[Dandekar, R.N., Ot ved k induizmu: Evoljucyonirujuščaja mifologija, Moskva, 2002].

Денисов, П.В., Религиозные верования чуваш [историко-этнографические очерки], Чебоксары, 1959.

[Denisov, P.V., Religioznyje verovanija čuvaš [istoriko-etnografičeskije očerki], Čeboksary, 1959.]

Державин, В.Н., Фантастика в «Страшной мести» Гоголя, in: Наукові записки Харківської науково-дослідчої катедри українознавства, № 6. Присвячується керовникові катедри акад. Д.І. Багалієві з нагоди 50-річчя його наукової діяльности, Харків, 1927, с. 329-338.

[Deržavin, V.N., Fantastika v «Strašnoj mesti» Gogolja, in: Naukovi zapysky Harkivskoji naukovo-doslidčoji katedry ukrajinoznavstva, № 6. Prysvjačujetsja kerovnykovi katedry akad. D.I. Bagalijevi z nagody 50-riččja jogo naukovoji dijalnosty, Harkiv, 1927, s. 329-338.]

Егоров, В.Г., Этимологический словарь чувашского языка, Чебоксары, 1964.

[Yegorov, V.G., Etimologičeskij slovar čuvašskogo jazyka, Čeboksary, 1964.]

Зороастрийские тексты. Суждения Духа разума [Дадестан-и меног-и храд]. Сотворение основы [Бундахишн] и другие тексты, издание подготовлено О.М. Чунаковой, Москва, 1997.

[Zoroastrijskije teksty. Suždenija Duha razuma [Dādestān ì mēnōg ì xrad]. Sotvorenije osnovy [Bundahishn] i drugije teksty, izdanije podgotovleno O.M. Čunakovoj, Moskva, 1997.]

Иванов, В.В., Опыт истолкования древнеиндийских ритуальных и мифологических терминов, образованных от asva - «конь»: [жертвоприношение коня и дерево asvattha в древней Индии], in: Проблемы истории языков и культуры народов Индии, Москва, 1974, c. $75-138$. 
[Ivanov, V.V., Opyt istolkovanija drevneindijskih ritualnyh i mifologičeskih terminov, obrazovannyh ot asva - «konj»: [žertvoprinošenije konja i derevo asvattha v drevnej Indii], in: Problemy istorii jazykov i kultury narodov Indii, Moskva, 1974, s. 75-138.]

Иванов, П., Очерк воззрений крестьянского населения Купянского уезда на душу и на загробную жизнь, in: Сборник Харьковского историко-филологического общества, т. XVIII, Харьков, 1909, с. 244-255.

[Ivanov, P., Očerk vozzrenij krestjanskogo naselenija Kupjanskogo ujezda na dušu i na zagrobnuju žyzn, in: Sbornik Harkovskogo istoriko-filologičeskogo obščestva, t. XVIII, Harkov, 1909, s. 244-255.]

Иванов, Юрий. Повесть Н.В. Гоголя «Страшная месть» и предания русинов севера Молдавии, in: Русин, № 4 (6), 2006, c. 150-154.

[Ivanov, Jurij. Povestj N.V. Gogolja «Strašnaja mest» i predanija rusinov severa Moldavii, in: Rusin, Nr. 4 (6), 2006, s. 150-154.]

Каманин, И., Научные и литературные произведения Н.В. Гоголя по истории Малороссии, in: Памяти Гоголя. Научно-литературный сборник, изданный Историческим обществом Нестора-летописиа, Киев, 1902, с. 75-132.

[Kamanin, I., Naučnyje i literaturnyje proizvedenija N.V. Gogolja po istorii Malorossii, in: Pamjati Gogolja. Naučno-literaturnyj sbornik, izdannyj Istoričeskim obščestvom Nestora-letopisca, Kijev, 1902, s. 75-132.]

Комиссаров, Г.И., Чуваши Казанскаго Заволжья, in: Известия общества археологии, истории и этнографии при Императорском Казанском университете, т. XXVII, вып. 5, Казань, 1911, с. 311-432.

[Komissarov, G.I., Čuvaši Kazanskago Zavolžja, in: Izvestija obščestva arheologii, istorii i etnografii pri Imperatorskom Kazanskom universitete, t. XXVII, vyp. 5, Kazan, 1911, s. 311-432.]

Комиссаров, Г.И., О чувамах: Исследования. Воспоминания. Дневники, письма, Чебоксары, 2003.

[Komissarov, G.I., O čuvašah: Issledovanija. Vospominanija. Dnevniki, pisma, Čeboksary, 2003.]

Литвинский, Б.А., Седов, А.В., Культы и ритуалы кушанской Бактрии. Погребальный обряд, Москва, 1984.

[Litvinskij, B.A., Sedov, A.V., Kulty i ritualy kušanskoj Baktrii. Pogrebalnyj obrjad, Moskva, 1984.]

Лыткин, В.И., Гуляев, Е.С., Краткий этимологический словарь коми языка, Москва, 1970.

[Lytkin, V.I., Guljajev, E.S., Kratkij etimologičeskij slovar komi jazyka, Moskva, 1970.]

Мельников, П.И. [Андрей Печерский], Очерки мордвы, Саранск, 1981.

[Melnikov, P.I. [Andrej Pečerskiy], Očerki mordvy, Saransk, 1981.]

Месарош, Дюла, Памятники старой чувашской веры, Чебоксары, 2000.

[Mészáros, Gyula, Pamjatniki staroj čuvašskoj very, Čeboksary, 2000.]

Миллер, Б.В., Тальшские тексты. Тексты, русский перевод и талышско-русско-франиузский словарь, Москва, 1930.

[Miller, B.V., Talyšskie tekstyi. Teksty, russkij perevod i talyšsko-russko-frantsuzskij slovar, Moskva, 1930.]

Миллер, Всев., Осетинские этюды. Часть вторая. Исследования, in: Ученье записки императорского Московского университета. Отдел историко-филологический. Выпуск второй, Москва, 1882.

[Miller, Vsev., Osetinskije etjudy. Čast vtoraja. Issledovanija, in: Učenyje zapiski imperatorskogo Moskovskogo universiteta. Otdel istoriko-filologičeskij. Vypusk vtoroj, Moskva, 1882.] 
Мокшин, Н.Ф., Мифология мордвы:: этнографический справочник, Саранск, 2004.

[Mokšyn, N.F., Mifologija mordvy: etnografičeskij spravočnik, Saransk, 2004.]

Напольских, В.В., Очерки по этнической истории, Казань, 2015.

[Napolskih, V.V., Očerki po etničeskoy istorii, Kazan, 2015.]

Народная демонология Полесья: Публикация текстов в записях 80-90-х г2. ХХ века. Т. 2. Демонологизация умерших людей, составители Л.Н. Виноградова, Е.Е. Левкиевская, Москва, 2012.

[Narodnaja demonologija Polesja: Publikacyja tekstov v zapisjah 80-90-h gg. XX veka. T. 2. Demonologizacyja umeršyh ljudej, sostaviteli L.N. Vinogradova, Je.Je. Levkijevskaja, Moskva, 2012.]

Невірова, К., Мотиви української демонольогії в «Вечорах» та «Миргороді» Гоголя, in: Записки Украӥнського Наукового Товариства в Київі, книга V, Київ, 1909, с. 27-60.

[Nevirova, K., Motyvy ukrajinskoji demonoljogiji v «Večorah» ta «Myrgorodi» Gogolja, in: Zapiski Ukrajinskogo Naukovogo Tovarystva v Kyjivi, kniga V, Kyjiv, 1909, s. 27-60.]

Нейкова, Ружа, Къде продължава животът, in: Български фолклор, кн. 2, София, 2008, с. 60-84.

[Nejkova, Ruža, Kde prodlžava živott, in: Blgarski folklor, kn. 2, Sofija, 2008, s. 60-84.]

Огибенин, Б.Л., Структура мифологических текстов Ригведы: [Ведийская космогония], Москва, 1968.

[Ogibenin, B.L., Struktura mifologičeskih tekstov Rigvedy: [Vedijskaja kosmogonija], Moskva, 1968.]

Одюков, И.И., Чувашские народные песни сочиального протеста и революиионной борьбы, Чебоксары, 1965.

[Odjukov, I.I., Čuvashskie narodnyje pesni socyalnogo protesta i revoljucyonnoj borby, Čeboksary, 1965.]

Персидские сказки, предисловие и перевод с персидского А.З. Розенфельд, Москва, 1958.

[Persidskije skazki, predislovije i perevod s persidskogo A.Z. Rozenfeld, Moskva, 1958.]

Петров, Н., Южно-русский народный элемент в ранних произведениях Гоголя, in: Памяти Гоголя. Научно-литературный сборник, изданный Историческим обществом Нестора-летописиа, Киев, 1902, с. 53-74.

[Petrov, N., Južno-russkij narodnyj element v rannih proizvedenijah Gogolja, in: Pamjati Gogolja. Naučno-literaturnyj sbornik, izdannyj Istoričeskim obščestvom Nestora-letopisca, Kijev, 1902, s. 53-74.]

Прокопьев, К.П., Похороны и поминки у чуваш, Казань, 1903.

[Prokopjev, K.P., Pohorony i pominki u čuvaš, Kazan, 1903.]

Рак, И.В., Мифы древнего и раннесредневекового Ирана [зороастризм], Санкт-Петербург, Москва, 1998.

[Rak, I.V., Mify drevnego i rannesrednevekovogo Irana [zoroastrizm], Sankt-Peterburg, Moskva, 1998.]

Ригведа. Мандаль I-IV, Москва, 1989.

[Rigveda. Mandaly I-IV, Moskva, 1989.]

Салмин, А.К., История чувашского народа: анализ основных версий, Санкт-Петербург, 2017.

[Salmin, A.K., Istorija čuvašskogo naroda: analiz osnovnyh versij, Sankt-Peterburg, 2017.]

Салмин, А.К., Народная обрядность чувашей, Чебоксары, 1994.

[Salmin, A.K., Narodnaja obrjadnost čuvašej, Čeboksary, 1994.] 
Салмин, А.К., Система фольк-религии чувашей, Санкт-Петербург, 2007.

[Salmin, A.K., Sistema folk-religii čuvašej, Sankt-Peterburg, 2007.]

Салмин, А.К., Традиционные обряды и верования чувашей, Санкт-Петербург, 2010.

[Salmin, A.K., Tradicyonnyje obrjady i verovanija čuvašej, Sankt-Peterburg, 2010.]

Салмин, А.К., Юпа - антропоморфный столб на могиле чувашей, in: Сибирский сборник-1, кн. 2: Погребальный обряд народов Сибири и сопредельных территорий, СанктПетербург, 2009, с. 204-210.

[Salmin, A.K., Yupa - antropomorfnyj stolb na mogile čuvašej, in: Sibirskij sbornik-1, kn. 2: Pogrebalnyj obrjad narodov Sibiri i sopredelnyh territorij, Sankt-Peterburg, 2009, s. 204-210.]

Семенов, А.А., Материаль для изучения наречия горных таджиков Центральной Азии, часть 2, Москва, 1900.

[Semenov, A.A., Materialy dlja izučenija narečija gornyh tadžykov Centralnoj Azii, čast 2, Moskva, 1900.]

Сказки народов Памира, Москва, 1976.

[Skazki narodov Pamira, Moskva, 1976.]

Сокаева, Д.В., Легенды и предания осетин: контекст традици: Монография, Владикавказ, 2010.

[Sokaeva, D.V., Legendy i predanija osetin: kontekst tradicyi: Monografija, Vladikavkaz, 2010.]

Стецюк, Вадим, Громовержечь та міф про чудесне народження, Львів, 2004.

[Stecjuk, Vadym, Gromoveržec ta mif pro čudesne narodžennja, Lviv, 2004]

Топоров, В.Н., О брахмане. К истокам концепции, in: Проблемы истории языков и культуры народов Индии, Москва, 1974, с. 20-74.

[Toporov, V.N., O brahmane. K istokam koncepcyi, in: Problemy istorii jazykov i kultury narodov Indii, Moskva, 1974, s. 20-74.]

Трофимов, А.А., Чувашская народная культовая скульптура, Чебоксары, 1993.

[Trofimov, A.A., Čuvašskaja narodnaja kultovaja skulptura, Čeboksary, 1993.]

Трофимов, Ю.А., Народная монументальная культовая скульптура чувашей и дунайских болгар: Проблемы исторической общности и художественной целостности, Чебоксары, 2003.

[Trofimov, Ju.A., Narodnaja monumentalnaja kultovaja skulptura čuvašej i dunajskih bolgar: Problemy istoričeskoj obščnosti i hudožestvennoj celostnosti, Čeboksary, 2003.]

Туганов, Махарбек, Литературное наследие. Орджоникидзе, 1977.

[Tuganov, Maharbek, Literaturnoje nasledije. Ordžonikidze, 1977.]

Федотов, М.Р., Этимологический словарь чувашского языка. В 2-х томах, том II: Сав Яштака, Чебоксары, 1996.

[Fedotov, M.R., Etimologičeskij slovar čuvašskogo jazyka. V 2-h tomah, tom II: Sav - Jaštaka, Čeboksary, 1996.]

Чибиров, Л.А., Традииионная духовная культура осетин, Москва, 2008.

[Čibirov, L.A., Tradicyonnaja duhovnaja kultura osetin, Moskva, 2008.]

Чубинский, П.П., Труды этнографическо-статистической экспедиции в западно-русский край, снаряжённой Императорским Русским Географическим Обществом. Материаль и исследования, собранные д.-чл. П.П. Чубинским. Том четвертый: Обряды:: родины, крестины, свадьба, похороны, Санкт-Петербург: типография В. Киршбаума, 1877. 
[Čubinskij, P.P., Trudy etnografičesko-statističeskoj ekspedicyi v zapadno-russkij kraj, snarjažonnoj Imperatorskim Russkim Geografičeskim Obščestvom. Materialy i issledovanija, sobrannyje d.-čl. P.P. Čubinskim. Tom četvertyj: Obrjady: rodiny, krestiny, svadba, pohorony, Sankt-Peterburg: tipografija V. Kirschbauma, 1877.]

Чувашские сказки, Москва, 1937.

[Čuvašskie skazki, Moskva, 1937.]

Чудаков, Г.И., Отражение мотивов народной словесности в произведениях Н.В. Гоголя, Киев, 1906.

[Čudakov, G.I., Otraženije motivov narodnoj slovesnosti v proizvedenijah N.V. Gogolja, Kijev, 1906.]

Чудаков, Г.И., Отношение творчества Гоголя к западно-европейским литературам, Киев, 1908.

[Čudakov, G.I., Otnošenije tvorčestva Gogolja k zapadno-jevropejskim literaturam, Kijev, 1908.]

Шенрок, В.И., Материаль для биографии Гоголя, том второй, Москва, 1893.

[Schoenrock, V.I., Materialy dlja biografii Gogolja, tom vtoroj, Moskva, 1893.]

Ящуржинский, Хр., Остатки языческих обрядов, сохранившиеся в малорусском погребении, in: Киевская старина, том XXVIII, январь, Киев, 1890, с. 130-132.

[Jaščuržynskij, Hr., Ostatki jazyčeskih obrjadov, sohranivšyjesja v malorusskom pogrebenii, in: Kijevskaja starina, tom XXVIII, janvar, Kijev, 1890, s. 130-132.]

Baitchura, Uzbek, On Some Principles of Etymology, in: Annali del Seminario di studi dell'Europa orientale: Sezione linguistico-filologica, Vol. 1, Napoli, 1982, p.1-68.

Dauenhauer, Anatol, Gogol's «Schreckliche Rache» und «Pietro von Abano» von L. Tieck, in: Zeitschrift für slavische Philologie, Bd. XIII, Doppeltheft 3/4, 1936, S. 315-318.

Driessen, F.C., Gogol as a Short-Story Writer: A Study of His Technique of Composition, The Hague, 1965.

Golden, Peter B., Turks and Iranians: Aspects of Türk and Khazaro-Iranian Interaction, in: Turkic-Iranian Contact Areas: Historical and Linguistic Aspects, Wiesbaden, 2006, p. 17-38.

Gombocz, Zoltän, Die bulgarisch-türkischen Lehnwörter in der ungarischen Sprache, Helsingfors, 1912.

Joki, Aulis J., Uralier und Indogermanen. Die älteren Berührungen zwischen den uralischen und indogernmanischen Sprachen, Helsinki, 1973.

Marzolph, Ulrich, Typologie des persischen Volksmärchens, Beirut-Wiesbaden, 1984.

Misra, Satya Swarup, The Date of the Rigveda and the Aryan Migration: Fresh Linguistic Evidence, in: The Indo-Aryan Controversy: Evidence and Interference in Indian History, London, New York, 2005, p. 181-233.

Munkacsi, Bernhard, Alanische Sprachdenkmäler im ungarischen Wortschatze, in: Keleti Szemle, vol. V, Budapest, 1904, S. 304-329.

Neykova, Ruzha, Shamanhood and the Bulgars, Sofia, 2009.

Rédei, Károly, Zu den indogermanisch-uralischen Sprachkontakten, Wien, 1986.

Róna-Tas, András, Language and History: Contributions to Comparative Altaistics, Szeged, 1986. 
THE THANATOLOGICAL MOTIFS OF A TERRIBLE VENGEANCE STORY BY MYKOLA GOGOL IN THE CONTEXT OF THE ETHNOCULTURAL CONNECTIONS OF THE UKRAINIANS

\section{KoSTYANTYN RAKHNO}

$\infty \infty$

Of all the stories by Mykola Gogol, A Terrible Vengeance is one of the most impressive and poetic. In this work, he shows a deep understanding of the culture and history of his nation. The story is based on Mykola Gogol's knowledge of the ancient folkways of Ukrainian life. A Terrible Vengeance, like other stories of the great writer, based on the everyday life and legends of his native Ukraine, focuses on the ancestral cemetery of a warlock, Kateryna's father. At this cemetery, his dead ancestors rise from their graves. After the warlock's demise, the dead tear him apart. Moreover, only the biggest and the oldest dead man, his ancestor Petro who committed the sin of fratricide, cannot get up. He cannot rise from earth to gnaw on his scion, and his motions cause earthquakes.

This notion of a cemetery where the oldest ancestor rules over everything is found in Chuvash mythology, where there is a belief in a so-called cemetery master. This position is assumed by the first buried man, usually a venerable, wise and generally respected old man whom all the deceased obey regardless of their status. They cannot leave the cemetery without his permission. The cemetery master was sometimes associated with the coming of death itself. He was supposed to take lives by rising from his grave and visiting the dying person. The cemetery was his land, and those "building a house" (that is, digging a grave) asked him for a place for a recently deceased person, sacrificing a piece of bread and a lump of cheese by leaving them at the site of the new grave. Sometimes they sacrificed money as well. During this ritual, the grave-diggers were asking the cemetery master for a piece of land. The latter consolidated all the reign of the cemetery world. He was supposed to accept the new arrival, allocate a place for him, teach him the rules of cemetery life, etc. It can be inferred that he was perceived as a giant. The cemetery master is virtually at the ruling position that is represented in the old age as the mythological metaphor of supremacy and power. This precedent is described in ancient Iranian and Indo-Arian texts - the first king on Earth, being the first deceased, becomes the deity of the underworld. It is Iranian folklore, among the Ossetians in particular, which shows the exact parallel to the concept that the first dead man loses the ability to move, he acquires cosmic size, and his movements cause earthquakes.

In the story, Petro committed a terrible sin connected with deceit and treachery, and the Zoroastrian texts speak about the same fall of the first dead. It is crucial that the Chuvash name of the pillar-like headstone, as well as the ritual alcoholic drink and cheese, are Indo-Iranian in origin. This alone points to the cattle-breeding, steppe, i.e., the Indo-Iranian roots of the entire ritual and concomitant beliefs, which show striking similarities to those in Ukraine. 
The money payment to the first dead man for a place at a cemetery is also of interest. It is known among the Chuvashes, the Ukrainians, and the Danube Bulgarians. Judging by a range of archaeological evidence, these beliefs existed among the Iranians of Middle Asia as well. Describing the burial site of the warlock's ancestors, Mykola Gogol mentioned the Ukrainian tradition of planting an arrow-wood tree at the grave site. The Chuvashes also had a tradition of planting this tree at the grave.

The motive of a father seeking the unnatural love of his daughter can be found in Ukrainian and Belorussian fairy-tales. However, the same plot is typical for the folklore of the Chuvashes and some Iranian-speaking nations - the Talishis, the Ossetians, the Persians, and the mountain Tajiks. It has some motives in common with Gogol's story, including the moment of the murder of Kateryna's son. The Chuvashes and the Ossetians have mythological beliefs about the travels of the soul during sleep, and these are reflected in the Ukrainian narratives and Mykola Gogol's story. The warlock's demise is described in accord with ancient Iranian religious beliefs. A Terrible Vengeance is based on ancient folkloric plots dating back to the ethnic substratum of the Ukrainians. It is one additional proof of Mykola Gogol's images being not mere literary constructs, but an integral part of the folk tradition.

Kostyantyn Rakhno, The Ceramology Institute, Academy of Sciences Ukraine, 102 Partizanska St., UKR-38164 Opishne, Ukraine, krakhno@ukr.net 